\title{
Hemşirelerde Hizmetkâr Liderlik ve Çalışan Performansının İncelenmesi
}

\section{Investigation of Servant Leadership and Employee Performance in Nurses}

\begin{abstract}
Özlem ÖZER ${ }^{\mathrm{a}}$
ÖZ Amaç: Bu çalışmanın amacı, hemşirelerin hizmetkâr liderlik algılarının çalışan performansı üzerindeki etkisini araştırmaktır. Çalışmanın bir diğer amacı ise, hemşirelerin hizmetkâr liderlik ve çalışan performansına yönelik algılarını sosyo-demografik değişkenler açısından incelemektir. Yöntem: Çalışma, tanımlayıcı türde bir araştırmadır. Çalışmanın evrenini İstanbul'da faaliyet göstermekte olan bir devlet hastanesinde görev yapmakta olan tüm hemşireler oluşturmaktadır. Araştırmada örneklem seçilmemiş, bütün hemşirelere ulaşılmaya çalışılmış ancak toplam 137 kişiden veri elde edilmiştir. Araştırmada katılımcıların hizmetkâr liderlik algılarını ölçmek için Hizmetkâr Liderlik Ölçeği kullanılırken, performanslarını ölçmek için Çalışan Performansı Ölçeği kullanılmıştır. Verilerin analizinde tanımlayıcı istatistikler, Mann Whitney U testi, Kruskal Wallis testi, korelasyon analizi ve regresyon analizi kullanılmıştır. Bulgular: Çalışmadan elde edilen sonuçlara göre, katılımcıların hizmetkâr liderlik ve çalışan performansına ilişkin puanlarının, görevlerine göre istatistiksel olarak anlamlı farklılıklar gösterdiği belirlenmiştir $(\mathrm{p}<0,05)$. Regresyon analizi sonucuna göre ise, hizmetkâr liderlik çalışan performansı üzerindeki toplam varyansın \%51,2'sini açıklamaktadır. Sonuç: Elde edilen sonuçlar, hemşirelerin performansını artırmasında liderlerinin, hizmetkâr liderlik özelliklerinin önemli olduğunu ortaya koymaktadır.
\end{abstract}

Anahtar Kelimler: Çalışan performansı, Hastane, Hemşire, Hizmetkâr liderlik

ABSTRACT Aim: This study aims to investigate of the impact of nurses' perceptions of servant leadership on employee performance. Another aim of the study is to examine the servant leadership and employee performance perceptions of nurses in terms of socio-demographic variables. Method: This research is a descriptive research. The universe of this study covers whole nurses who serve in a public hospital in Istanbul. In the study, sampling method was not applied, the whole nurses was tried to be reached, but the data were obtained from total 137 participants. While the Servant Leadership Scale was used to measure the servant leadership perceptions of participants, Employee Performance Scale was used to measure performance in the study. Descriptive statistics, Mann Whitney U test, Kruskal Wallis test, correlation analysis and regression analysis were used in the analysis of the data. Results: According to the results derived from the study, the participants' scores on servant leadership and employee performance showed statistically significant difference in line with their duties $(\mathrm{p}<0.05)$. As a result of the regression analysis, servant leadership explains the $51.2 \%$ of total variance on employee performance. Conclusion: The results show that the servant leadership qualities of the leaders are important in increasing the performance of the nurses. Keywords: Employee performance, Hospital, Nurse, Servant leadership

\section{Giriş}

Liderlik ve liderlik fenomeninin incelenmesi, temelini medeniyetin başlangıcına dayandırmaktadır (1). Ekonomik, siyasi ve örgütsel sistemlerin başarısının, bu sistemlerin liderlerinin etkin ve etkili rehberliğine bağlı olması nedeniyle de liderlik, davranış bilimlerinde en kapsamlı şekilde araştırılan konulardan bir tanesi olmuştur (2).

Liderlik, "bir bireyin, bir grup çalışanı ortak bir hedefe ulaşabilmesi için etkilediği bir dizi süreçtir" (3). Bir diğer tanıma göre ise liderlik; çalışanlarını etkileyerek, amaç ve hedeflerin gerçekleştirilmesi yolunda onları yönlendirmek ve yönetmektir (4). Literatürde liderlik ve lider davranışlarını açıklamaya çalışan çeşitli kuram ve

Geliş Tarihi/Received:23-03-2018/Kabul Tarihi/Accepted: 27-08-2018

aDr. Öğr. Üyesi, Burdur Mehmet Akif Ersoy Üniversitesi, İktisadi ve İdari Bilimler Fakültesi, Sağlı Yönetimi Bölümü, e-mail: oozer@mehmetakif.edu.tr ORCID: 0000-0002-7238-5371

Atıf: Özer Ö. Hemşirelerde Hizmetkâr Liderlik ve Çalışan Performansının İncelenmesi. Sağlık Bilimleri ve Meslekleri Dergisi 2019; 6(1):105-112

Citation: Özer Ö. Investigation of servant leadership and employee performance in nurses. Journal of Health Science and Profession 2019;6(1): 105112

HSP 2019;6(1):105-112 
yaklaşımlar yer almaktadır. Bu kuramlara dayalı olarak da liderler; demokratik, otokratik, katılımc1, paternalist gibi farklı liderlik tarzlarını benimseyebilmektedir. Literatür incelendiğinde, liderlik tarzlarına ek olarak "hizmetkâr liderlik" kavramının da son yirmi yıl içerisinde yeni bir liderlik tarzı olarak kendini göstermeye başladığ 1 görülmektedir (5).

Bu çalışmada ele alınan hizmetkâr liderlik kavramı, ilk kez Greenleaf tarafından 1970'li yıllarda ortaya atılmıştır. Greenleaf (2002), hizmetkâr liderin öncelikle bir hizmetkâr olduğunu, kişinin hizmet etmek için hizmet etme isteğinin doğal bir his ile başladığını ve liderlik yapmanın bilinçli bir tercih olduğunu belirtmektedir (6). Spears (1996)'a göre ise hizmetkâr liderlik, başkalarına öncelikli olarak hizmet etmeyi ifade eden bir modeldir. Bu model, çalışmak için bütüncül bir yaklaşımı, topluluk duygusunu teşvik etmeyi ve karar vermede gücün paylaşımını vurgulamaktadır (7). Hizmetkâr liderlik, örgütsel hedeflerin ilk olarak örgütü oluşturan bireylerin genel iyilik halini ve gelişimini kolaylaştırarak, uzun vadeli bir temelde elde edilebileceği inancına sahiptir. Bu nedenle de hizmetkar liderlik, liderlerin takipçilerinin endişelerine dikkat etmeleri ve onlarla empati kurması gerektiğini vurgulayan bir liderlik tarzıdır (8).

Hizmetkâr liderlik, farkındalık ve kendini tanıma yoluyla liderin gelişimine odaklanmaktadır. Kendi üzerine düşünme ve farkındalık, bir liderin amaçlarını, inançlarını ve bireysel özelliklerini anlamasını sağlamaktadır. Bu süreç, kişinin kişisel vicdanının yanı sıra temel etik ve ahlaki düşüncelerinin de gelişmesine yardımcı olmaktadır (9). Spears (2010) hizmetkâr bir liderde on temel özelliğin bulunduğunu vurgulamaktadır. $\mathrm{Bu}$ özellikler; dinleme, empati, iyileşme, farkındalık, ikna etme, kavramsallaştırma, öngörü, kahyalık, insanların gelişimine bağlılık, topluluk oluşturma şeklindedir (10). Russel ve Stone (2002) ise hizmetkâr liderlik özelliklerini iki şekilde incelemektedir. Buna göre birincil özellikler; vizyon, dürüstlük, doğruluk, güven, hizmet, modellik, öncülük ve başkalarının beğenisi iken, diğer özellikler; iletişim, güvenilirlik, yetkinlik, kahyalık, görünürlük, etki, ikna, dinleme, teşvik etme, öğretme ve yetki vermedir (11).

Çalışmada incelenen bir diğer değişken olan performans, amacın gerçekleştirilme derecesi olarak belirtilmektedir. Bir başka ifadeyle performans, bir işi yapan bireyin, grubun ya da örgütün $o$ iş aracılığıla, hedefe göre nereye ulaşabildiğini göstermektedir (12). Sağlık hizmetlerinde performans ise, sağlik hizmetini son mesleki bilgi ve becerilerle, en uygun malzemeleri kullanarak, zamanında eksiksiz, doğru ve güvenilir bir şekilde sonuçlandırarak hastaya sunmak ve iletmek şeklinde tanımlanmaktadır (13). Sağlık hizmetlerinden hasta memnuniyetinin sağlanması, daha iyi bir sağlık düzeyine erişilmesi, hizmet sunum süreci ölçümünün doğru yapılarak ödüllendirmesi ve altyap1 ve girdilerinin kalite ölçümünün yapılması gibi kriterler sağlık hizmetleri açısından önemli performans ölçütleri olarak değerlendirilmektedir (14).

Hizmetkâr liderlik, lider hemşirelerin başkalarının ihtiyaçlarına dikkate almasını ve hemşirelerin kişisel gelişimini artırmasını, bakım kalitesini geliştirmesini, ekip çalışmasına değer vermesini, kişisel katılımını ve bakım davranışını geliştirmesini gerektirmektedir (15). Hizmetkâr liderlik, iş ortamlarına kattığ 1 samimiyet, paylaşım ve güven duyguları ile bireylerin iş tatminleri, performansları gibi örgütsel bağlılığı artırıc1 kavramlarla yakından ilgilidir (16). Greenleaf'ın hizmetkâr liderlik modeli de, çalışanların ihtiyaçlarına öncelik verir ve örgütsel performansın ve çalışan memnuniyetinin artırılmasını sağlayan bir liderlik modeli olarak görülür $(15,17)$. Literatürde de, kollektivist toplumlarda hizmetkâr liderlik davranışlarının uygulanmasının yüksek çalışan performansı elde etmek için faydalı olacağ 1 belirtilmektedir (18).

$\mathrm{Bu}$ çalışmanın amacı da, hemşirelerin hizmetkâr liderlik algılarının çalışan performansı üzerindeki etkisinin araştırılması ve hemşirelerin hizmetkâr liderlik ve çalışan performansına yönelik algılarının sosyo-demografik değişkenler açısından incelenmesidir. Literatürde sağlik alanında ve hemşireler üzerinde hizmetkâr liderlik ve çalışan performansını bir arada inceleyen çalışmaların sınırlı olması ise bu çalışmanın temel çıkış noktasını oluşturmaktadır.

\section{Materyal ve Metot}

Araştırmanın Türü: Çalışma, tanımlayıcı nitelikte bir araştırmadır.

Araştırma Soruları: Hemşirelerin hizmetkâr liderlik ve çalışan performansına yönelik algıları sosyo-demografik değişkenlere göre farkl1lık 
göstermekte midir?, Hemşirelerin hizmetkâr liderlik algıları çalışan performansını etkiler mi? şeklindedir.

Evren ve Örneklem: Çalışmanın evrenini İstanbul ilinde yer alan bir devlet hastanesinde çalışan hemşireler $(\mathrm{N}=236)$ oluşturmaktadır. Çalışmada örneklem seçilmemiştir. Araştırmada kullanılan veri toplama aracı çalışmaya katılmayı kabul eden tüm hemşirelere dağıtılmış (145) ve 137 kişiden geri dönüş sağlanmıştır.

Veri Toplama Aracı: Çalışmada veri toplama aracı olarak, iki ölçekten ve kişisel ve demografik bilgilerden oluşan anket formu kullanılmıştır. Kişisel ve demografik bilgiler kısmında yaş, cinsiyet, eğitim durumu, hastanedeki görev, medeni durum, sağlik sektöründe ve mevcut birimde toplam çalışma süresi olmak üzere toplam 7 soru yer almaktadır.

Calıșmada katılımcıların hizmetkâr liderlik algılarını ölçmek için Liden vd. (2015) tarafindan geliştirilen (19), Kılıç ve Aydın (2012) tarafından da Türkçe geçerlilik ve güvenilirliği yapılan (18) "Hizmetkâr Liderlik Ölçeği kullanılmıştır. Ölçek tek boyuttan ve 7 maddeden (örn. şahsi bir problemim olduğunda yöneticimden yardım isteyebilirim gibi) oluşmaktadır. Ölçekteki maddelere ilişkin katılım düzeyleri "Kesinlikle Katılmıyorum=1", ve "Kesinlikle Katıliyorum=5" şeklinde puanlandırılmaktadır. Çalışmada kullanılan hizmetkâr liderlik ölçeğinin iç tutarlılık katsayısı Kılıç ve Aydın (2012) tarafından 0.87 olarak bulurken, bu çalışmada iç tutarlılık katsayısı 0,86 olarak bulunmuş ve ölçeğin güvenilir olduğu sonucuna ulaşılmıştır.

"Çalışan Performansı Ölçeği" ise Șehitoğlu (2010)'nun doktora tezinden alınmıştır (20). Ölçek tek boyuttan ve 7 maddeden (örn. bir çalışan olarak memnuniyet seviyem yüksektir, devamsızlık oranlarım düşüktür, moralim yüksektir gibi) oluşmaktadır. Ölçeklerdeki maddelere ilişkin katılım düzeyleri "Kesinlikle Katılmıyorum=1", "Katılmıyorum=2", "Kararsızım=3", "Katılıyorum=4" ve "Kesinlikle Kat1lyorum=5" şeklinde puanlandırılmaktadır. Şehitoğlu (2010) çalışmasında çalışan performansı ölçeğinin iç tutarlılık katsayısını 0,878 olarak bulurken, bu çalışmada iç tutarlılık katsayıs1 0,790 olarak bulunmuş ve bu ölçeğin de güvenilir olduğu sonucuna ulaşılmıştır.
Verilerin Analizi: Verilerin analizinde SPSS 20.0 paket programı kullanılarak tanımlayıcı analizler, güvenirlik analizi, korelasyon analizi ve regresyon analizi yapılmıştır. Ayrıca çalışmada yaş, cinsiyet, medeni durum, toplam çalışma süresi, mevcut birimde çalışma süresi ve görev değişkenleri arasındaki farklılı̆̆ test etmek için Mann Whitney U testi kullanılırken; eğitim durumları arasındaki farklılığı test etmek için Kruskal Wallis testi kullanılmıştır.

Etik İzin: Çalışmanın yürütülebilmesi için Mehmet Akif Ersoy Üniversitesi Girişimsel Olmayan Klinik Araştırmalar Etik Kurulu'ndan (Karar No:GO2018/52) izin alınmıştır. Hemşirelere çalışmaya katılımın gönüllü olduğu ve toplanan verilerin sadece bilimsel amaçla kullanılacağı ifade edilmiştir.

\section{Bulgular}

Tablo 1'de görüldüğü gibi, araştırmaya katılan hemşirelerin büyük bir bölümü $(\% 82,5)$ kadınlardan oluşmaktadır. Katılımcıların \%51,1 $(\mathrm{n}=70)^{\prime}$ i 35 yaş ve altında; \%51,8 $(\mathrm{n}=71)$ 'i evli; $\% 61,3$ ( $\mathrm{n}=84$ )'ü lisans düzeyinde eğitim seviyesine sahiptir.

Tablo 1. Araştırmaya Katılan Hemşirelerin Tanımlayıcı Özellikleri

\begin{tabular}{llcc}
\hline Değişkenler & & $\mathrm{n}$ & $\%$ \\
\hline Cinsiyet & Kadın & 113 & 82,5 \\
& Erkek & 24 & 17,5 \\
\hline Yaş & $\leq 35$ & 70 & 51,1 \\
& $\geq 36$ & 67 & 48,9 \\
\hline Medeni Durum & Evli & 71 & 51,8 \\
& Bekâr & 66 & 48,2 \\
\hline \multirow{3}{*}{ Eğitim Durumu } & Önlisans & 36 & 26,3 \\
& Lisans & 84 & 61,3 \\
& Lisansüstü & 17 & 12,4 \\
\hline Çalışma Süresi & $\leq 10$ & 56 & 40,9 \\
(yıl) & $\geq 11$ & 81 & 59,1 \\
\hline Mevcut Birimde & $\leq 7$ & 67 & 48,9 \\
Çalışma Süresi & $\geq 8$ & 70 & 51,1 \\
(yıl) & & & \\
\hline \multirow{3}{*}{ Görev } & Yönetici /Servis & 25 & 18,2 \\
& Sorumlusu & 112 & 81,8 \\
& Hemşire & &
\end{tabular}

Toplam

$137 \quad 100$

Katılımc1ların \%59,1 $(\mathrm{n}=81)$ 'i 11 yıl ve üzeri toplam çalışma süresine; $\% 51,1 \quad(n=70) ' i$ ise 
mevcut birimde 8 yıl ve üzeri çalışma süresine sahiptir. Katılımc1ların sadece \%18,2 ( kısmı yönetici hemşire konumundadır.

Tablo 2' de yer alan araştırma değişkenlerine ilişkin temel istatistiklere bakıldığında, hemşirelerin hizmetkâr liderlik algıları 3,44 $\pm 0,52$ ve çalışan performansına ilişkin algıları $3,95 \pm 0,41$ olarak bulunmuştur. Hemşirelerin hizmetkâr liderlik ve çalışan performansı algıları 5'li Likert Ölçeği ile değerlendirilmesi nedeniyle, ortalama skorlar "5" değerine yaklaştıkça ilgili boyutun düzeyi en yükseği, "1" değerine yaklaştıkça ise en düşüğü göstermektedir. Buna göre bu çalışmaya katılan hemşirelerin hizmetkâr liderlik algılarının orta seviyede ve çalışan performansı algılarının da ortalamanın biraz üzerinde bir seviyede olduğu söylenebilir. Hizmetkâr liderlik ile çalışan performansı arasındaki korelasyonların ise pozitif yönde ve yüksek düzeyde olduğu görülmektedir $(\mathrm{r}=0,715 ; \mathrm{p}<0,01)$

Tablo 2. Hizmetkâr Liderlik ve Çalışan Performansına İlişkin Ortalama, Standart Sapma ve Korelasyon

\begin{tabular}{|l|c|c|c|}
\multicolumn{4}{c|}{ Değerleri } \\
\hline Değişkenler & Ort \pm SS & $\begin{array}{c}\text { Hizmetkar } \\
\text { Liderlik }\end{array}$ & Çalışan Performans1 \\
\hline Hizmetkâr Liderlik & $3,44 \pm 0,52$ & 1 & 1 \\
\hline Çalışan Performans1 & $3,95 \pm 0,41$ & $0,715^{* *}$ & \\
\hline$* *$ Korelasyon anlamlı 0.01 (two-tailed) & & & \\
\hline
\end{tabular}

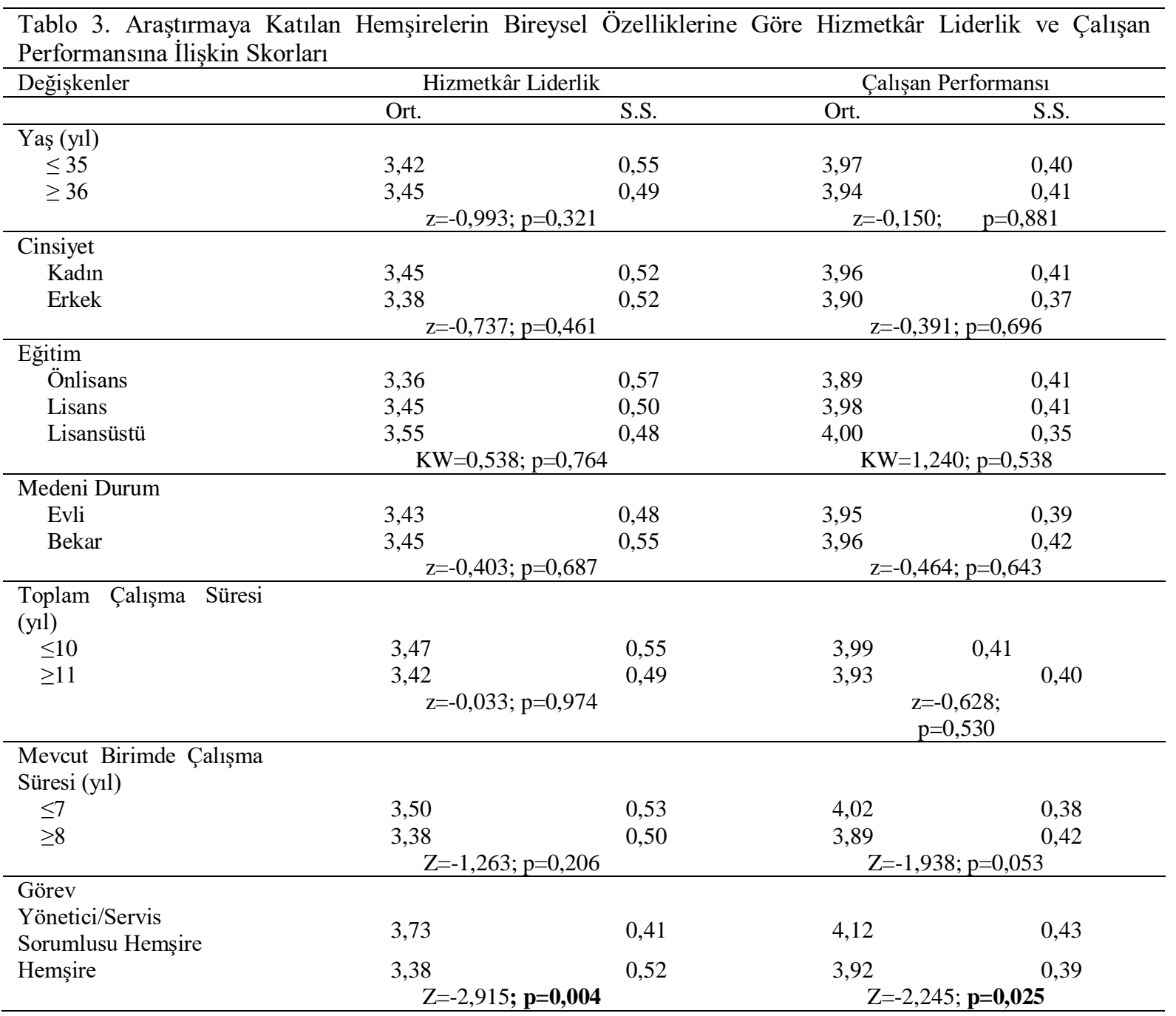


Tablo 3'de araştırmaya katılan hemşirelerin hizmetkâr liderlik ve çalışan performansı algılarına ilişsin puanları yaş, cinsiyet, eğitim durumu, medeni durum, toplam çalışma süresi, mevcut birimde çalışma süresi ve görev değişkenlerine göre karşılaştırılmış ve yürütülen test sonuçları gösterilmiştir. Buna göre, hemşirelerin hizmetkâr liderlik $(Z=-2,915 ; p<0,05)$ ve çalışan performans1na $(Z=-2,245 ; p<0,05)$ ilişkin değerlendirmelerinin sadece görev değişkeni açısından istatistiksel olarak anlamlı farklılıklar gösterdiği tespit edilmiştir. Yönetici hemşirelerin hizmetkâr liderlik ve çalışan performansına ilişkin puanları daha yüksek bulunmuştur.
Araştırmaya katılan hemşirelerin hizmetkâr liderlik ve çalışan performansına ilişkin değerlendirmeleri, araştırma kapsamında incelenen diğer değişkenler olan yaş, cinsiyet, eğitim durumu, medeni durum, toplam çalışma süresi ve mevcut çalışma süresine göre $\mathrm{p}>0,05$ olmas1 nedeniyle istatistiksel olarak anlamlı biçimde farklılık göstermediği tespit edilmiştir. Ancak anlamlı farklılık bulunmamakla beraber, kadın, lisansüstü eğitim düzeyine sahip, bekâr, toplam çalışma süresi 10 yil ve daha az olan, mevcut birimde ise 7 yıl ve daha az çalışma süresine sahip olan hemşirelerin hizmetkâr liderlik ve çalışan performansı puanları daha yüksek bulunmuştur.

Tablo 4. Regresyon Analizi Sonuçları

\begin{tabular}{lcccccc}
\hline Değişken & B & $\begin{array}{c}\text { Std. } \\
\text { Hata }\end{array}$ & $\beta$ & t & p & VIF \\
\hline (Sabit) & 2,025 & 0,164 & & 12,337 & 0,000 & \\
Hizmetkâr Liderlik & 0,561 & 0,047 & 0,715 & 11,890 & 0,000 & 1,000 \\
\hline$R=0,715, R^{2}=0,512$ & $D$ n
\end{tabular}

$R=0,715, R^{2}=0,512$, Durbin Watson=1,51; $F=141,363, p<0,001$

Tablo 4'de hizmetkâr liderliğin çalışan performans1 üzerindeki etkilerini ortaya koymak amacıyla çok değişkenli regresyon analizi yürütülmüştür. Oluşturulan regresyon modeline ilişkin Durbin Watson katsayısının 2,5'in altında olması ve Varyans Artış Faktör (VIF) katsayılarının 10'dan az olması çoklu bağlantı ve otokorelasyonun olmadığını göstermektedir (21). Regresyon modeline ilişkin istatistiksel tahminler modelin anlamlı ve kullanılabilir olduğunu göstermektedir $(\mathrm{F}=141,363 ; \mathrm{p}<0,01)$. Hizmetkâr liderlik çalışan performansı üzerindeki toplam varyansın \%51,2'sini açıklamaktadır. Regresyon modelinde, regresyon katsayısının anlamlılığına ilişkin t-testi sonuçları incelendiğinde, katılımcıların hizmetkâr liderlik $(\mathrm{t}=11,890$; $\mathrm{p}<0,01) \quad$ algılarının yükselmesi çalışan performansına ilişkin algılarını istatistiksel olarak artırmaktadır.

\section{Tartışma}

Hemşireler hastalara daha kaliteli bir sağlık bakımı sunmak için gerekli bilgiye, profesyonel yönetim ve liderlik becerilerini gerektiren sorumluluklara sahiptir. Dolayısıyla da hemşireler, sağlık kurumlarında liderlik yapma konusunda önemli bir grubu temsil etmektedir (22). Liderlik, örgütsel bağl1lık ve iş tatmini gibi örgütsel etkinliği, hemşirelerin görev performansını ve hemşirelik hizmetlerini etkileyen önemli faktörlerden birisidir. $\mathrm{Bu}$ yüzden yöneticilerin liderliği desteklemek ve yönetmek için çaba göstermesi önemli bir konudur (23).

$\mathrm{Bu}$ çalsşmada, hemşirelerin hizmetkâr liderliğe ilişskin algılarının çalışan performansı üzerindeki etkisinin araştırılması ve hemşirelerin hizmetkâr liderlik ve çalışan performansına yönelik algılarının sosyo-demografik değişkenler açısından incelenmesi amaçlanmıştır. Sağlık kurumlarında hemşireler özelinde bu konuyu ele alan çalışmaların yetersiz olması nedeniyle, çalışmanın alana katkı sağlayacağı düşünülmektedir.

Çalışmada yapılan analizler neticesinde hizmetkâr liderlik ve çalışan performansı arasındaki korelasyonlar pozitif yönde ve yüksek düzeyde bulunmuştur. Ayrıca hemşirelerin hizmetkâr liderlik algılarının orta seviyede olduğu tespit edilmiştir. Uğurluoğlu vd. (2015)'nin özel bir hastanede sağlık çalışanları üzerinde gerçekleştirdikleri çalışmalarında da katılımcıların hizmetkâr liderlik algılarının orta düzeyde olduğu belirlenmiştir (2). Topaloğlu ve Yalçıntaş (2017)'ın belediyelerde görev alan işgörenler üzerinde gerçekleştirdikleri çalışmalarında ise katılımcıların 
genel hizmetkâr liderlik algıları yüksek düzeyde bulunmuştur (24). Çalışmada hemşirelerin çalışan performansına ilişkin puanlarının, ortalamanın biraz üzerinde bir seviyede olduğu belirlenmiştir. Uzuntarla vd. (2016)'nin sağlık çalışanlarının performanslarını inceledikleri çalışmalarında çalışan performansının düşük olduğu belirlenmiştir (25). Korkmazer vd. (2016) sağlık çalışanlarının performansını 4,1; Kılınç ve Paksoy (2017) ise 4,21 ile yüksek bir seviyede olduğunu tespit etmiştir (26,27). Yine Sayg1lı vd. (2016), Koçak ve Özüdoğru (2012), Kartal (2017) da bu çalışmanın sonuçlarına benzer olarak sağlık çalışanlarının performans düzeylerinin ortalamanın üzerinde olduğunu belirlemişlerdir $(28,29,30) . \quad \mathrm{Bu}$ bulgulardan hareketle, sağlık kurumlarının en önemli insan kaynaklarından birisini oluşturan hemşirelerin, liderlerinin hizmetkâr liderliğe yönelik özelliklerinden orta düzeyde memnuniyet duyduğu ve performanslarından genel olarak memnun oldukları sonucu ortaya çıkmaktadır.

Çalışmada oluşturulan regresyon modeline göre hizmetkâr liderlik çalışan performansı üzerindeki toplam varyansın \%51,2'sini açıklamaktadır. Regresyon modelinde, regresyon katsayısının anlamlılığına ilişkin t-testi sonuçları incelendiğinde, katılımcıların hizmetkâr liderlik algılarının yükselmesi çalışan performansına ilişkin algılarını istatistiksel olarak artırmaktadır. Satır (2017)'in Kayseri ili Organize Sanayi Bölgesindeki bir işletmede çalışan 159 kişi ile gerçekleştirmiş olduğu çalışmasında çalışanların hizmetkâr liderlik algılamalarının görev ve bağlamsal performansları ile anlamlı bir etkileşime sahip olduğu sonucuna ulaşılmıştır (31). Stefánsdóttir (2013)'in İzlanda'da sağlik kuruluşlarında gerçekleştirdiği çalışmasının sonucuna göre de kurumlarda hizmetkâr liderliğin varlığ1 durumunda daha iyi bir örgütsel performansın ortaya çıktığı belirlenmiştir (32). Koçak ve Özüdoğru (2012)'nun sağlık sektöründeki yöneticilerin liderlik özelliklerinin çalışanların motivasyonu ve performansı üzerindeki etkilerini inceledikleri çalışmalarında, yöneticilerin liderlik özelliklerinin çalışanların performansını etkilediği, yöneticilerin liderliği ile çalışanların performansı arasında aynı yönlü güçlü bir ilişkinin olduğu belirlenmiştir (29). Yapılan regresyon analizi sonucunda elde edilen bulgulara göre sağlık kurumlarında hemşirelerin çalışan performans1 düzeylerini artırabilmek için hizmetkâr liderliğin sağlanmasının önemli olduğu ortaya koyulmuştur. $\mathrm{Bu}$ yüzden hemşirelerin çalışan performansını artırmak adına yöneticilerin çalışanlarına karşı yardımsever, yol gösterici, etik ilkeler doğrultusuna hareket etmesinin önemli olduğu düşünülmektedir.

Çalışmada araştırmaya katılan hemşirelerin hizmetkâr liderlik ve çalışan performansına ilişkin değerlendirmelerinin sadece görev değişkeni açısından istatistiksel olarak anlamlı farklılıklar gösterdiği tespit edilmiştir. Buna göre, yönetici hemşirelerin hizmetkâr liderlik ve çalışan performansına ilişkin puanları daha yüksek bulunmuştur. Kartal (2017) sağlık çalışanlarının performans düzeyleri ortalamalarının yönetsel pozisyona göre farklılık gösterdiğini bulmuş, yönetsel pozisyonu olan sağlık çalışanlarının performans düzeylerinin herhangi bir yönetsel pozisyonu olmayanlara göre daha yüksek olduğunu tespit etmiştir (30). Kılınç ve Paksoy (2017)'un çalışmasında ise sağlık çalışanlarının idari görev olma durumu ile çalışan performansı düzeyi puan ortalamaları arasında istatistiksel olarak anlamlı bir farklılık saptanmamıştır (27). Hastanelerde, hemşirelerin hastalara bakım sağlama fonksiyonlarını yerine getirebilmeleri için gerekli ortamın hazırlanması, malzeme ve insan kaynağının koordine edilmesi, hastane yönetimi, hekimler ve hastanenin diğer birimleri arasında hemşirelik hizmetlerinin sunumu açısından iletişim ve koordinasyonun sağlanması gibi görevleri yönetici hemşireler yerine getirmektedir. $\mathrm{Bu}$ görevlerin aksatılması veya uygun bir şekilde yapılmaması, verilen bakım hizmetinin sunulama-masına veya hizmet kalitesinin düşmesine neden olacağından yönetici hemşirelerin yüksek performans göstermeleri önemli bir konudur.

Çalışmada hemşirelerin çalışan performansına yönelik algıların eğitim durumuna göre anlamlı bir farklılık gösterdiği bulunamamasına rağmen, lisansüstü eğitim düzeyine sahip katılımcıların diğer eğitim düzeyine sahip hemşirelerden daha yüksek bir performans gösterdikleri belirlenmiştir. Tayfun ve Çatır (2013)'ın hemşireler üzerinde gerçekleştirdiği çalışmalarında ise eğitim değişkeni ile çalışanların performansı arasında anlamlı bir farklılık bulunmuş, önlisans ve lisans mezunu çalışanların lise mezunu çalışanlara göre daha fazla performans gösterdiği belirlenmiştir (33). 
Hizmetkâr liderlik, son yıllarda birçok hemşire yöneticisi tarafindan uygulamalarına rehberlik eden bir model olarak benimsenmiştir. Hizmetkâr liderlik tarzı, çalışanlar arasında güven oluşturmaya ve takipçilerine liderlerinin refahlarını gerçekten önemsediğine dair inancı aşılamaya çalışan bir modeldir (34). Dolayısıyla da hizmetkâr liderlik özelliklerinin sergilendiği sağlik kurumlarında, çalışanların daha yüksek işe katılım göstermesi ve daha yüksek performans sergilemesi beklenmektedir.

\section{Sonuç}

Elde edilen sonuçlar, hemşirelerin performansını artırmasında liderlerinin, hizmetkâr liderlik özelliklerine sahip olmasının önemli olduğunu ortaya koymaktadır. Dolayısıyla bir kurumda etkili hizmetkâr liderlik özelliklerinin sergilenmesi, çalışanların performansını daha yüksek seviyelere çıkarılmasına yardımcı olacaktır. Bu yüzden sağlık kurumlarında öncelikli olarak liderlerin çalışanlarına karşı samimi, yardımsever, çalışanlarının kariyer gelişimini destekleyen, etik ilkelerden taviz vermeyen bir tutum sergilemelerinin önemli olduğu düşünülmektedir.

$\mathrm{Bu}$ çalışmanın sonuçlarının tüm hemşirelere genellenmesi konusunda sinırlılıkları vardır. $\mathrm{Bu}$ çalışma, sadece İstanbul'da ve sadece bir devlet hastanesinde yapılmıştır. Dolayısıyla tüm sağlık kurumlarına yönelik bir genelleme yapılması söz konusu değildir. Gelecekte, Türkiye'nin farklı şehirlerinde ve farklı sağlık kurumlarında yapılacak çalışmalarla daha etkili sonuçlar ortaya konulabileceği düşünülmektedir.

\section{Kaynaklar}

1. Stone AG, Patterson K. Research Roundtable, School of Leadership Study, Regent University 2005 [Erişim tarihi: 03.03.2018], Erişim adresi:

https://www.regent.edu/acad/global/publicatio ns/sl_proceedings/2005/stone_history.pdf

2. Uğurluoğlu Ö, Durukan Köse S, Köse T. Sağlık çalışanlarının hizmetkâr liderlik algılarının lider-üye etkileşimi ve örgütsel güven üzerindeki etkisi. Türkiye Sosyal Araştırmalar Dergisi, 2015;19(2):239-262.

3. Northouse PG. Leadership: Theory and practice. (5th ed). Thousand Oaks, CA: SAGE Publications; 2010. p.3
4. Mirze SK. İşletme. İstanbul: Literatür Yayıncilik; 2010. p.144.

5. Ürü Sanı FO, Çalışkan SC, Atan Ö, Yozgat U. Öğretim üyelerinin hizmetkâr liderlik davranışları ve ardılları üzerine bir araştırma. Ege Akademik Bakış, 2013;13(1): 63-82.

6. Bakan İ, Doğan İF. Hizmetkâr liderlik. Kahramanmaraş Sütçü İmam Üniversitesi İktisadi ve İdari Bilimler Fakültesi Dergisi, 2014;2(2):1-12.

7. Spears L. Reflections on Robert K. Greenleaf and servant-leadership. Leadership \& Organization Development Journal, 1996;17(7):33-35.

8. Olesia WS, Namusonge GS. Servant leadership: The exemplifying behaviours. IOSR Journal Of Humanities and Social Science, 2014;19(2):75-80.

9. Trastek VF, Hamilton NW, Niles EE. Leadership models in health care-A case for servant leadership. Mayo Clin Proc, 2014;89(3):374-381.

10. Spears LC. Character and servant leadership: Ten characteristics of effective, caring leaders. The Journal of Virtues \& Leadership, 2010;1(1): 25-30.

11. Russell RF, Stone AG. A review of servant leadership attributes: developing apractical model. Leadership \& Organization Development Journal, 2002,23(3):145-157.

12. Bayram L. Geleneksel performans değerlendirme yöntemlerine yeni bir alternatif: 360 derece performans değerlendirme. Sayıştay Dergisi, 2006;62:47-65.

13. Tengilimoğlu D, Işık O, Akbolat M. Sağlık işletmeleri yönetimi. 4. Basım. Ankara: Nobel Akademik Yayınc1lı; 2012. p.387.

14. Aydın S, Demir, M. Sağlikta performans yönetimi-performansa dayalı ek ödeme sistemi, Sağlikta Dönüşüm Serisi-2. Ankara: Onur Matbaacıl1k Ltd. Şti.; 2006. p.31-33.

15. Hall HH. An exploration of the relationship between servant leadership characteristics of nurse leaders and the perceptions of empowerment among their followers. Dissertation. Indiana Wesleyan University; 2015.

16. Dinçer M, Öksüz B. Hizmetkar liderlik anlayış1 ile örgütsel vatandaşlık davranışı geliştirmek. Erciyes İletişim Dergisi, 2011;2(2):2-18. 
17. Greenleaf R.K. Servant leadership: A journey into the nature of legitimate power and greatness. 25th Ed. New Jersey, USA: Robert K. Greenleaf Center, Inc.; 2002.

18. Kılıç KC, Aydın Y. Hizmetkâr liderlik ölçeğinin Türkçe uyarlaması: Güvenirlik ve geçerlik çalışması. KMÜ Sosyal ve Ekonomik Araştırmalar Dergisi, 2016;18(30):106-113.

19. Liden RC, Wayne SJ, Meuser J, Hu J, Wu J, Liao C. Servant leadership: Validation of a short form of the SL-28. The Leadership Quarterly, 2015;26(2):254-269.

20. Şehitoğlu Y. Örgütsel sessizlik örgütsel vatandaşlık davranışı ve algılanan çalışan performansı ilişkisi. Doktora tezi, Gebze: Gebze İleri Teknoloji Enstitüsü; 2010.

21. Hair JF, Anderson RE, Tatham RL, Black, WC. Multivariate data analysis. New Jersey: Prentice Hall; 1998.

22. Duygulu S, Kublay G. Yönetici hemşirelerin ve birlikte çalıştıkları hemşirelerin liderliğe ilişkin değerlendirmeleri ve yönetici hemşirelerin sahip oldukları liderlik özellikleri. Hacettepe Üniversitesi Sağlik Bilimleri Fakültesi Hemşirelik Dergisi, 2008;1-15.

23. Park MH, Hwang CJ. Relationship between servant leadership of nurse managers and positive thinking and organizational commitment of nurses. Korean Comparative Government Review, 2015;19(1):49-77.

24. Topaloğlu C, Yalçıntaş M. The relationship between servant leadership behaviours and organisatinal citizenship behaviour and work satisfaction in local governments. Global Business Research Congress (GBRC), May 2425, 2017, Istanbul, Turkey.

25. Uzuntarla Y, Ceyhan S, Fırat İ. Çalışan performansının incelenmesi: Sağlık sektörü örneği. Gülhane Tip Dergisi, 2017;59:16-20.

26. Korkmazer F, Ekingen E, Yıldız A. Psikolojik sermayenin çalışan performansına etkisi: Sağlık çalışanları üzerinde bir araştırma. Hacettepe Sağlik İdaresi Dergisi, 2016;19(3):271-281.

27. Kılınç P, Paksoy M. Sağlık çalışanlarında performans alg1 düzeyinin bazı sosyodemografik değişkenlere göre incelenmesi. Selçuk Üniversitesi Sosyal Bilimler Meslek Yüksekokulu Dergisi, 2017;20(2):151-159.
28. Saygılı M, Erigüç G, Özer Ö. Sağlık çalışanlarının örgütsel sessizlik ve çalışan performans1 düzeylerinin belirlenmesi. The Journal of Academic Social Science Studies, 2016;49:485-500.

29. Koçak DR, Özüdoğru H. Yöneticilerin liderlik özelliklerinin çalışanların motivasyonu ve performansı üzerindeki etkileri: Kamu ve özel hastanelerinde bir uygulama. Ticaret ve Turizm Eğitim Fakültesi Dergisi, 2012;1:7688.

30. Kartal N. Sağlık çalışanlarında işe cezbolma, işe yabancılaşma ve performans arasındaki ilişkinin değerlendirilmesi. Yüksek Lisans Tezi, Ankara: Hacettepe Üniversitesi Sosyal Bilimler Enstitüsü; 2017.

31. Satır F. İşgörenlerin otantik ve hizmetkâr liderlik algılamalarının performansları üzerine etkileri: Kayseri Organize Sanayi Bölgesinde bir işletme uygulaması. Yayınlanmamış yüksek lisans tezi. Nevşehir: Nevşehir Hacı Bektaş Veli Üniversitesi, Sosyal Bilimler Enstitüsü; 2017.

32. Stefánsdóttir KH. Are there signs of a better organizational performance in the presence of servant leadership?. Thesis, Iceland: Reykjavik University; 2013.

33. Tayfun A, Çatır O. Örgütsel sessizlik ve çalışanların performansları arasındaki ilişki üzerine bir araştırma. İşletme Araştırmaları Dergisi, 2013;5(3):114-134.

34. Sherman RO. Servant leadership in nursing.2012, [Erişim tarihi: 24.05.2018], Erişim adresi: http://www.emergingrnleader.com/wpcontent/uploads/2013/08/The-Best-ofEmerging-RN-Leader-2011-2013.pdf 